\title{
Meraih Prestasi dengan Menerapkan Nilai Kebenaran
}

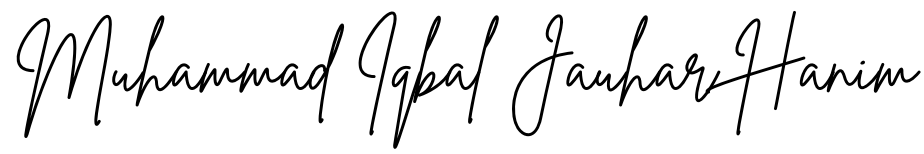

Prestasi merupakan sesuatu yang ingin dicapai oleh setiap manusia. Prestasi juga menjadi tolak ukur keberhasian karir seseorang. Meraih prestasi juga dapat dijadikan sebagai pencapaian seseorang. Oleh karena sifat manusia yang tidak pernah dan tidak akan puas, maka setelah meraih pencapaian pasti manusia menginginkan sesuatu yang lebih lagi. Hal tersebut wajar dan sangat manusiawi apabila diraih dengan cara yang benar dan wajar. Hal sederhana tampak dari seseorang yang telah berhasil menyelesaikan studi pada jenjang tertentu, maka dia menginginkan untuk melanjutkan studi lagi pada jenjang yang lebih tinggi. Hal ini sah-sah saja dan dapat dinilai masyarakat umum sebagai sesuatu hal yang prestisius dan membanggakan. Prestasi merupakan sesuatu yang dapat membedakan kualitas individu dengan individu yang lainnya. Contohnya dalam dunia kerja yaitu ketika seorang Kepala Human Resource Development melakukan seleksi terhadap calon kandidat, maka hal yang dapat dilakukan yaitu membandingkan prestasi diantara semua kandidat, sebelum melakukan penilaian yang lainnya. Seseorang yang menginginkan adanya peningkatan prestasi dalam karirnya, sebaiknya diperoleh dengan cara-cara yang benar.

Idealnya meraih prestasi tentu dilalui dengan cara yang benar, namun pada kenyataannya seringkali dijumpai seseorang 
yang menginginkan cara instan untuk mendapatkannya, sehingga memilih untuk berbuat yang tidak benar. Contoh nyata yang sering dijumpai di lingkungan pendidikan yaitu masih adanya peserta didik yang mencontek pekerjaan teman, seorang mahasiswa yang melakukan plagiasi untuk tugas karya tulisnya, seorang mahasiswa yang "titip absen" kepada temannya sehingga dinilai hadir dalam perkuliahan, penulis juga menjumpai laporan hasil kerja lapangan yang tidak seutuhnya benar sesuai pengalaman dan pengamatan di lapangan. Masalah-masalah tersebut dapat diatasi dan diperbaiki dengan pemahaman nilai kebenaran yang baik dan sikap integritas untuk menjalakannya dalam kehidupan sehari-hari.

Manusia dilahirkan dengan hati nurani. Dalam ilmu sosiologi dijelaskan bahwa terdapat norma kesusilaan yang berdasarkan pada hati nurani. Diakui maupun tidak diakui, mengerjakan sesuatu dengan tidak dilandasi cara yang benar akan menghasilkan perasaan yang khawatir, cemas, dan tidak tentram. Seandainya seseorang ingin berprestasi dengan cara yang tidak benar, pertanyaan besarnya adalah mau sampai kapan hal tersebut terus dilakukan? Untuk menjawab itu semua dikembalikan lagi kepada kesadaran yang telah dimiliki oleh masing-masing individu supaya mendapatkan pemahaman tentang nilai kebenaran untuk meraih prestasi dalam hidup.

Sebagai seorang akademisi, metode mencari kebenaran sebenarnya telah diajarkan untuk dapat diterapkan dalam proses menggali data. Data bermakna sahih apabila data tersebut telah memenuhi unsur validitas (benar) dan reliabilitas (ajeg). Dikatakan benar apabila data tersebut benar adanya, tidak direkayasa, dan sesuai dengan kondisi sesungguhnya di lapangan. Pemahaman seseorang terhadap nilai kebenaran menurut penulis dapat ditingkatkan dengan cara sebagai berikut: 1) bersedia mendengarkan kajian maupun webinar dari narasumber berkompetensi yang bersifat refleksi diri dan perbaikan menuju ke arah yang lebih 
baik, (2) membaca buku mengenai nilai kebenaran, bahwa mengerjakan sesuatu hendaknya dengan cara yang benar dan menyadari kekeliruan yang selama ini dilakukan dalam usaha meraih prestasi, (3) bersikap terbuka (open minded) terhadap seseorang yang peduli terhadap kita dan mau mengingatkan kita bahwa ada sesuatu yang tidak benar dalam proses meraih prestasi, (4) sejenak merenung apakah selama ini sudah berusaha meraih prestasi dengan cara yang benar, (5) belajar dari kesalahan yang dilakukan orang lain terkait ketidakbenaran dalam proses meraih prestasi, (6) segera berkomitmen dan menerapkan nilai kebenaran dalam usaha untuk mencapai sebuah tujuan.

Berdasarkan pengalaman penulis, sebagai upaya menambah pemahaman tentang nilai kebenaran dalam meraih prestasi memanglah tidaklah mudah. Pemahaman tersebut dipelajari dari waktu ke waktu sebab penulis telah bertekad untuk melaksanakan belajar sepanjang hayat. Pemahaman nilai kebenaran sebenarnya dapat ditanamkan sejak dini kepada peserta didik sekolah dasar. Hal-hal sederhana seperti pesan jangan berbohong, datanglah tepat waktu, buanglah sampah pada tempatnya, merupakan penerapan dari nilai kebenaran sejak usia dini. Tantangannya yaitu ketika seseorang sudah memiliki pemahaman tentang nilai kebenaran, terdapat situasi dimana lingkungan sosialnya tidak mengerjakan hal-hal yang benar dan dianggap biasa. Akhirnya orang yang telah memahami nilai kebenaran menjadi terpengaruh untuk melakukan sesuatu seperti yang dikerjakan oleh lingkungan sosialnya.

Kita tentu tidak mengharapkan fenomena tersebut terjadi pada diri kita, dan kalaupun akhirnya kita terjebak dalam situasi tersebut, penulis menyarankan agar setiap dari kita memiliki keberanian untuk dilihat berbeda dari kebanyakan orang. Contohnya yaitu ketika sebagian pegawai datang terlambat pada sebuah rapat dan sudah dianggap lumrah, maka kita sebagai orang yang memiliki pemahaman tentang nilai kebenaran maka

\section{Republik Indonesia Berpihak Pada Kebenaran}


jangan ikut-ikut untuk melakukan hal tersebut. Kita harus memiliki keberanian untuk datang lebih awal sehingga tidak terlambat dalam mengikuti kegiatan rapat. Meskipun hal tersebut tampak berbeda dan mencolok karena lingkungan sosial sudah biasa untuk datang terlambat mengikuti rapat.

Keberanian diperlukan untuk menerapkan nilai kebenaran dalam meraih prestasi. Namun hal tersebut tidak selamanya berjalan lancar dalam kehidupan sehari-hari. Adakalanya menerapkan nilai kebenaran mendapatkan pertentangan dari kelompok sosial. Pertentangan tersebut tampak dari sikap tidak menerima, protes, bahkan yang paling ekstrim lagi sampai melakukan boikot kepada seseorang yang menjalankan nilai kebenaran. Hal tersebut terjadi lantaran dianggap tidak menguntungkan dan merugikan bagi kelompoknya. Dalam kehidupan akademis misalnya ketika seorang mahasiswa mengingatkan dosennya untuk mengumpulkan tugas, padahal dosen tersebut sejatinya telah lupa bahwa sudah memberikan tugas bagi mahasiswanya. Maka mahasiswa "benar" yang mengingatkan dosennya tadi akan mendapatkan pertentangan dari mahasiswa yang tidak mengumpulkan tugas karena belum mengerjakannya. Hal tersebut oleh penulis dapat dijelaskan sebagai tantangan dalam menerapkan nilai kebenaran dalam kehidupan sehari-hari dan hal tersebut adalah wajar. Menerapkan nilai kebenaran konsekuensinya yaitu tidak disenangi kelompok sosial yang belum menerapkan nilai kebenaran.

Tantangan lain dari upaya berbuat benar dalam kehidupan sehari-hari yaitu tentang konsistensi dalam menerapkannya. Seringkali ada seseorang yang hari ini berbuat benar namun besok berbuat salah. Ini pun juga manusiawi, sebab pada hakikatnya manusia merupakan tempatnya salah dan lupa. Maka dari itu harus saling mengingatkan dalam hal kesabaran dan juga kebajikan. Untuk dapat menjawab tantangan konsistensi 
berbuat benar, maka diperlukan dukungan dari lingkungan sosial. Lingkungan sosial yang terbiasa dengan budaya berbuat benar biasanya merupakan lingkungan yang disiplin. Apabila kita merasa di lingkungan sekitar tidak ada yang mendorong dan mengingatkan kita untuk berbuat benar, maka jadilah agen sosial untuk merubah kondisi tersebut. Dalam upaya menjadi agen sosial tersebut tentu saja diperlukan pemahaman yang baik dan benar tentang nilai kebenaran.

Kebenaran ada yang bersifat pribadi dan bersifat kelompok. Ciri menonjol yang membedakan kebenaran pribadi dan kebenaran kelompok yaitu kebenaran pribadi berasal dari individu, sedangkan kebenaran kelompok berasal dari kelompok. Hal yang harus diingat yaitu sesuatu yang sudah dianggap benar oleh kita, belum tentu juga dianggap benar oleh orang lain. Hal tersebut karena kebenaran dapat juga bersifat pribadi. Contohnya yaitu seorang perempuan karir pulang malam karena ada tugas lembur di kantornya. Dia merasa benar karena telah menyelesaikan pekerjaannya dan dapat kembali ke rumahnya dengan selamat. Namun hal tersebut belum tentu dinilai benar oleh tetangganya karena perempuan yang pulang malam tanpa didampingi muhrim dinilai perempuan nakal. Seharusnya perempuan pulang ke rumah lebih sore. Perbedaan persepsi terhadap nilai kebenaran inilah yang seharusnya menjadi perhatian kita untuk dapat bersikap tenggang rasa karena tidak semua cerita kehidupan manusia dapat kita ketahui. Kita juga tidak bisa sembarangan menilai orang dan gemar menyalahkan orang. Sebuah adagium, jika seseorang gemar menyalahkan orang tanpa mau berintrospeksi, maka dialah sesungguhnya orang yang salah tersebut. Kebenaran kelompok menurut pemahaman penulis yaitu kebenaran yang telah menjadi kesepakatan dalam sebuah kelompok masyarakat. Contohnya yaitu dalam sebuah tim sepak bola telah disepakati bahwa tidak boleh ada pemain tim yang terkena kartu merah dari wasit, 
karena dapat merugikan tim. Berdasarkan ilustrasi tersebut, nilai kebenaran kelompok yaitu apabila pemain dalam pertandingan berhasil tidak mendapatkan kartu merah. Sebaliknya apabila terdapat pemain mendapatkan kartu merah, maka dianggap melanggar kebenaran kelompok yang disepakati sebelum pertandingan.

Menambah pemahaman mengenai nilai kebenaran sesungguhnya tidak dapat dipisahkan dari nilai dan norma. Maksudnya sebelum jauh merenungkan tentang nilai kebenaran, alangkah bijaknya apabila mempelajari nilai dan norma. Nilai adalah sesuatu yang dianggap benar dan dan baik di masyarakat. Sedangkan norma adalah seperangkat peraturan yang disepakati bersama untuk mencapai nilai di masyarakat. Berbagai norma di masyarakat yaitu norma agama, norma sosial, norma susila, norma adat istiadat, dan norma hukum. Melakukan pelanggaran norma berarti bersiap menghadapi konsekuensinya, seperti mendapat hukuman maupun sanksi sosial dari masyarakat. Sebaliknya, melaksanakan norma dengan sebaik mungkin, maka akan mendapatkan nilai yang baik di masyarakat.

Berbuat benar dalam kehidupan sehari-hari memiliki manfaat yang dapat dirasakan langsung oleh pelakunya, maupun manfaat tidak langsung, seperti timbulnya kepercayaan dari masyarakat di lingkungan sekitar karena menilai kita berkomitmen dan akan selalu berbuat benar. Sedangkan manfaat langsung yang dapat dirasakan seperti hati menjadi tenang, lebih fokus terhadap pekerjaan, dan tidak dihantui rasa khawatir karena yakin telah berbuat benar. Intinya kalau berbuat benar itu merupakan sebuah kegembiraan, maka mengapa kita harus memilih untuk berbuat salah dalam usaha mencapai tujuan? Hal ini menjadi renungan agar kita menjadi pribadi yang lebih baik kedepannya.

Dalam kehidupan akademis, menerapkan nilai kebenaran berarti memuaskan banyak pihak, serta mendapatkan bonus 
ketentraman hati dan penghargaan diri yang baik. Memang seperti itulah kondisi idealnya yang harus ada dalam lingkungan pendidikan. Dengan ketentraman hati, seorang dosen dapat menjalankan tri dharma perguruan tinggi dengan baik. Mahasiswa juga dapat menuntaskan tugas akhir tepat pada waktunya. Selain itu, membiasakan diri untuk berbuat benar berarti mengkondisikan diri agar lebih berintegritas. Seperti diketahui berintegritas berarti memegang prinsip kejujuran, konsistensi, dan keberanian dalam diri. Hal ini dapat merangsang pikiran bawah sadar kita dalam memaksimalkan potensi diri sebagai upaya meraih prestasi secara kontinyu.
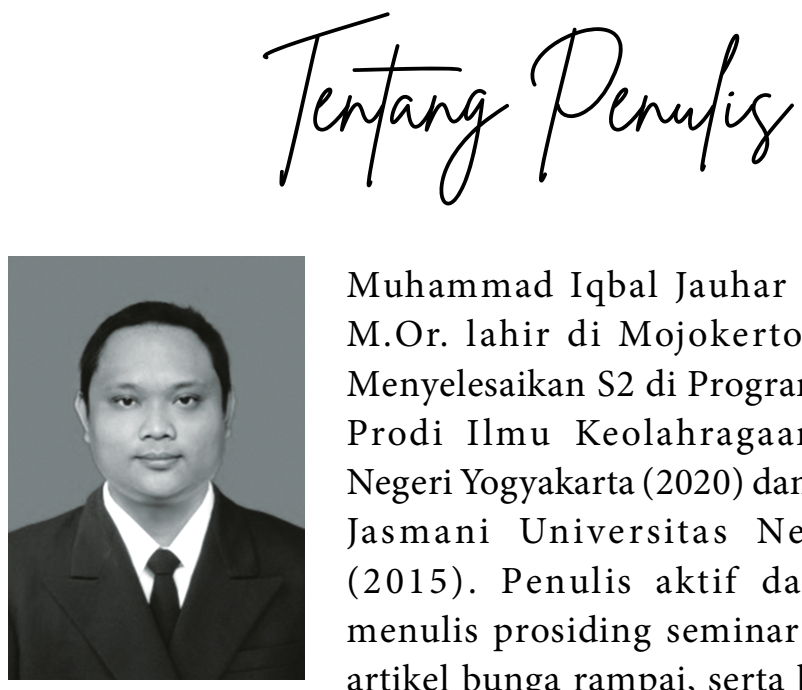

Muhammad Iqbal Jauhar Hanim, S.Pd., M.Or. lahir di Mojokerto, Jawa Timur. Menyelesaikan S2 di Program Pascasarjana Prodi Ilmu Keolahragaan Universitas Negeri Yogyakarta (2020) dan S1 Pendidikan Jasmani Universitas Negeri Malang (2015). Penulis aktif dalam kegiatan menulis prosiding seminar internasional, artikel bunga rampai, serta beberapa karya tulis lainnya. Penulis senang untuk berdiskusi mengenai pendidikan dan sport science dapat dihubungi via email: iqbaljauharhanim@gmail.com. 